\title{
Comprehensive Care for Hemophiliacs
}

- Activities of North Kyushu Hemophilia Genter at the University

Hospital of Occupational and Environmental Health, Japan -

Akira Shirahata, Orie Ono, Yuriko Yanaga, Masao Yamaguchi and Keiichi Oosato,

University Hospital of Occupational and Environmental Health, Japan. Yahatanishi-ku, Kitakyushu 807, Japan

\section{Introduction}

Patients with congenital bleeding disorders, particularly with hemophilia suffer from handicaps in various aspects of social life including school attendance, employment, marriage, etc., because even a minor trauma may cause a massive bleeding. Their joint disorder (hemophiliac arthropathy), which results from recurrent joint bleeding, limits the range of motion, leading to difficulties in their activities of daily life. Moreover, infection with human immunodeficiency virus (HIV) and/or hepatitis $\mathrm{C}$ virus via blood coagulation factor concentrates, causes large physical and psychological burdens for hemophiliacs $[1-3]$.

In order to improve the quality of life (QOL) of hemophiliacs with such a variety of problems, hemostatic treatment by pediatricians or physicians is far from sufficient, but cooperation among doctors from various relevant departments such as dentists, nurses, medical social workers, clinical psychologists and others is essential to deal with the variety of problems of hemophiliacs. Therefore, we opened the North Kyushu Hemophilia Center (hereinafter, referred to as "the Center") in 1984 for the purpose of giving total care to hemophiliacs at the University Hospital of Occupational and Environmental Health, Japan $[4,5]$. In this paper, we would like to introduce its activities during these 10 years and describe the difficulties we have had.

\section{Organization of the Center}

Director General of the Center is held concurrently by the Director of the Hospital, and the actual core of activities is the Management Committee: which is composed of the members shown in Fig. 1. However, there is no full- 


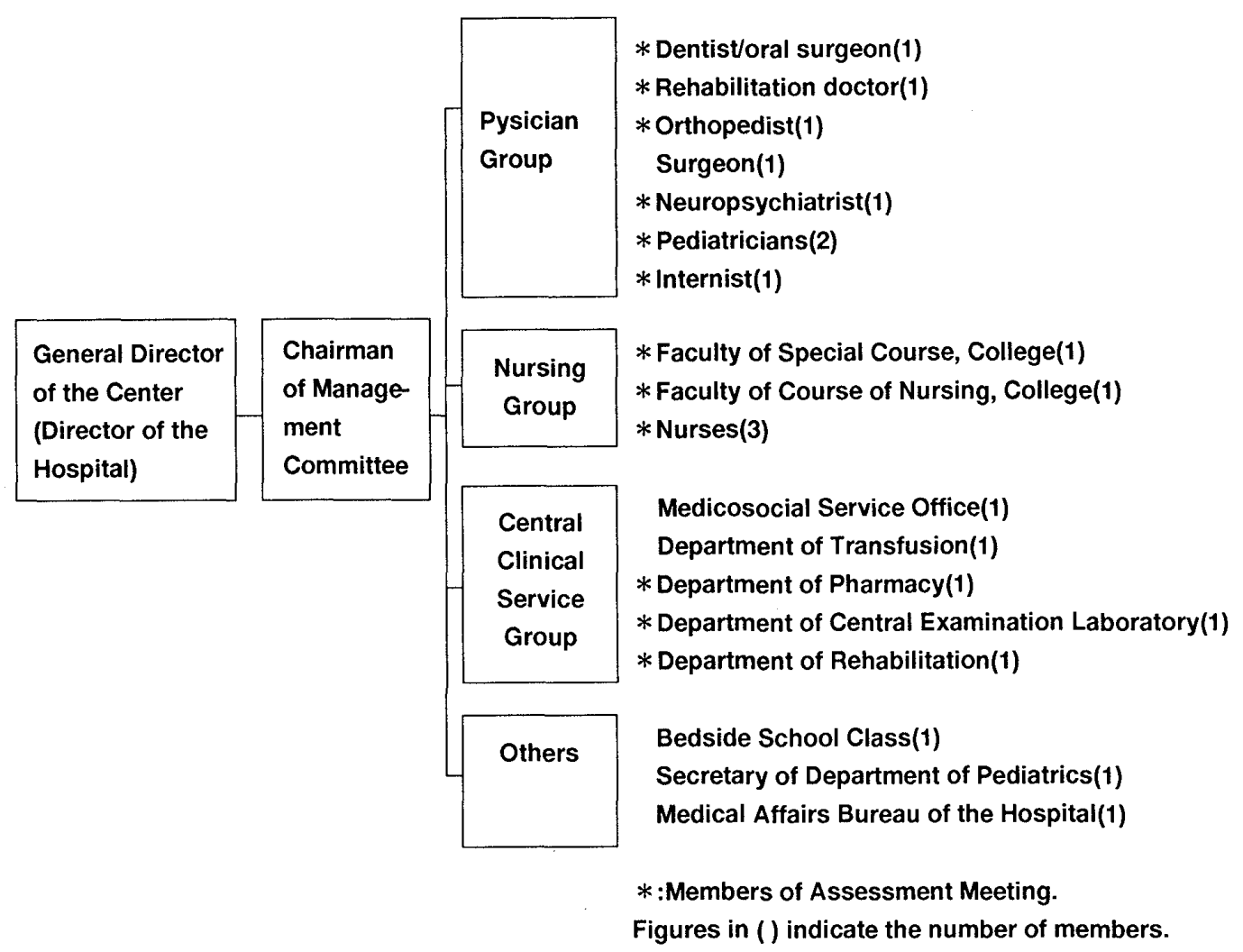

Fig. 1. Organization of North Kyushu Hemophilia Center.

service personnel and most of the Committee Members concurrently hold another post. Three part-time employees dedicated to the Center's job are engaged in preparation and official work for the comprehensive outpatient clinic service and Assessment Meetings as well as consultation for hemophiliacs about a variety of problems.

The Center is located in the Medicosocial Service Office of the Hospital, and is equipped with private extension and outside telephone lines, a facsimile machine, a copier machine, personal computers and other office supplies. Unlike the kidney center or cardiological centers, there are no exclusive medical devices. Blood collection or infusion of blood products can be performed in a room of the common outpatient clinic office described later, which is adjacent to the Center. The interview room which is within the Medicosocial Office is available, and is very convenient for interviews or counseling regarding for example, HIV infection.

\section{Comprehensive Outpatient Clinic Service}

In order to provide hemophiliacs with comprehensive support, it is important to recognize the full range of problems of each patient. For this purpose, the Genter is operating comprehensive outpatient clinic service once a month. In the comprehensive outpatient clinic service, patients start with a detailed interview by a 


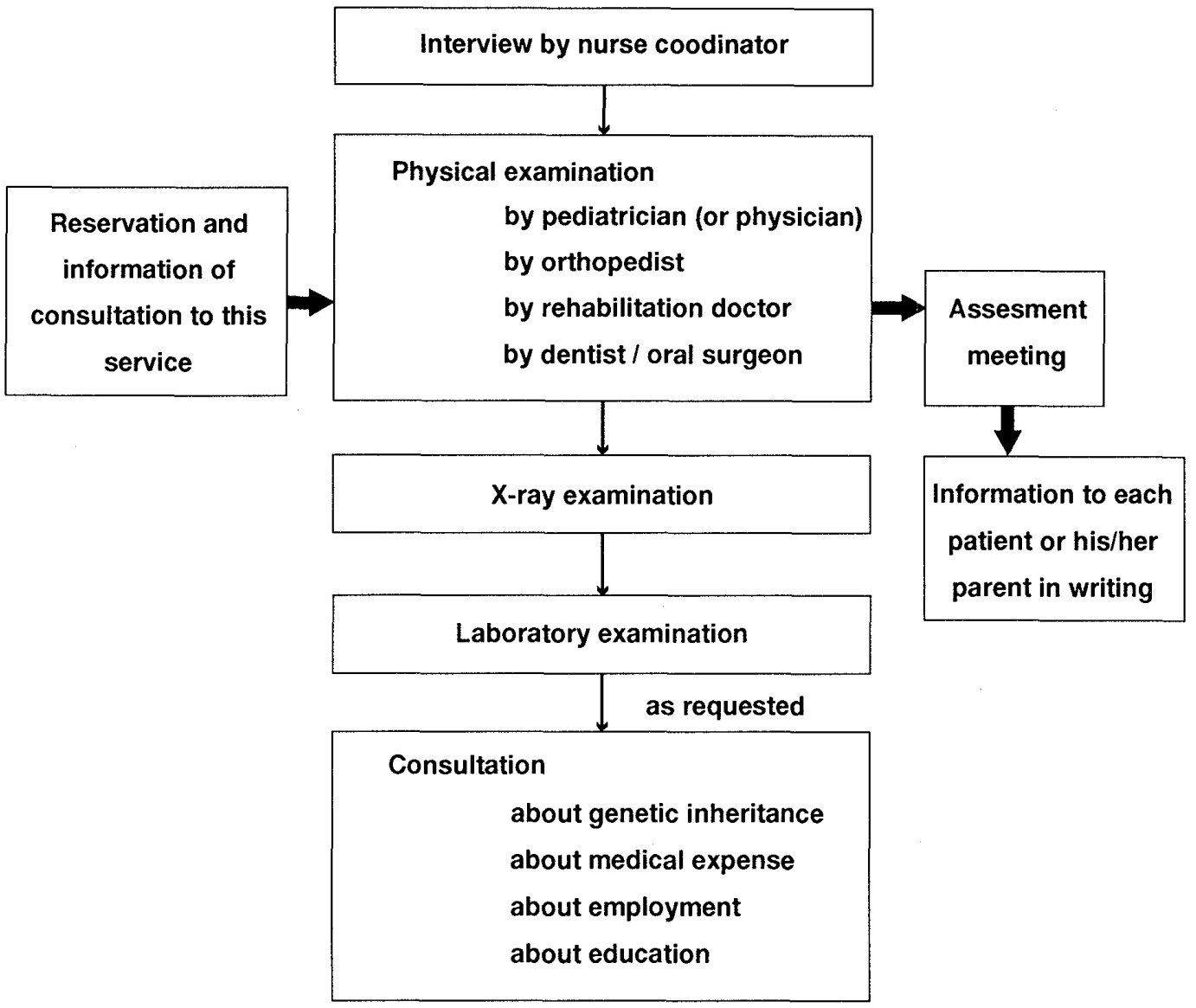

Fig. 2. Contents of the comprehensive outpatient clinic service.

nurse coordinator, and receive a physical examination by a pediatrician (or physician, in the case of adult patients), orthopedist, rehabilitation doctor, and a dentist/oral surgeon, as well as X-ray and laboratory examinations. Consultation about genetic inheritance, medical expenses, employment, and education is available as requested (Fig. 2). Different specialists gather in one place to perform the respective examinations because it is inconvenient for patients to move from one department to another. About five years ago, the Health Administration Center was used for this purpose, but after the construction of the common outpatient clinic with five examination rooms adjacent to the Center, this clinic has been used. Examinations performed in one place have several advantages: the efficiency is improved, and it also allows communication among examiners. The comprehensive outpatient clinic service is given on a reservation basis, and each patient receives this service once a year, in principle.

Two or three weeks after the comprehensive outpatient clinic service, the assessment meeting is held. Attendance is the nurse coordinator, doctors in charge of examinations, and members marked with $*$ in Fig. 1, and the method of total care for each patient is discussed based on the findings obtained from the comprehensive 


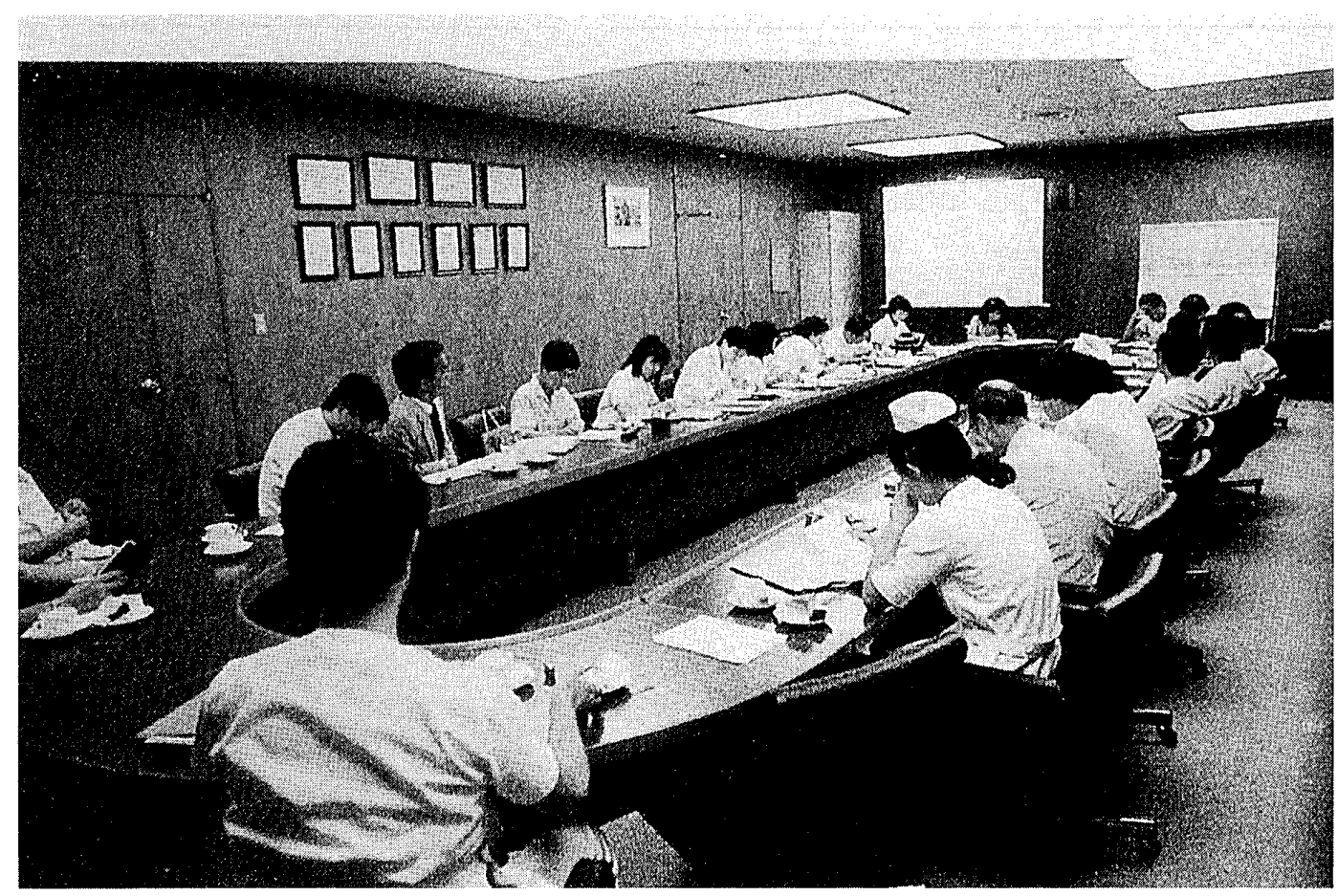

Fig. 3. Assessment meeting.

outpatient clinic service (Fig. 3). Each patient or his/her parents receives the conclusion of the discussion along with the examination findings in writing. Notification in writing requires much time and labor and is quite a burden for the nurse coordinator. However, we have continued this method because we think it is very important in order to make our intention understood by the patient.

All findings obtained from the comprehensive outpatient clinic service are recorded in the medical record of the pediatric department, which eliminates the necessity of preparing a number of separated records for different departments. If the findings indicate the necessity of additional examination or treatment in another department, then a medical record for each department will be prepared. By December 1995, 119 comprehensive outpatient clinic services or 580 patient-day examinations were performed. A total of 142 patients, including those with von Willebrand's disease, are now registered in the Center (Table 1).

Table 1. Numbers of registrated patients and consultations of hemophiliac patients and/or their families

\begin{tabular}{ccccc}
\hline Galendar year & Hemophilia A & Hemophilia B & Others & Consultation* $^{*}$ \\
\hline 1990 & 108 & 17 & 20 & 243 \\
1991 & 114 & 19 & 24 & 373 \\
1992 & 120 & 20 & 24 & 358 \\
1993 & 126 & 21 & 24 & 331 \\
1994 & 130 & 22 & 24 & 325 \\
1995 & 136 & 23 & 26 & 344 \\
\hline
\end{tabular}

*excluding the consultations on the day of comprehensive outpatient clinic. 


\section{Approach to Musculoskeletal Problems}

Among the comprehensive supports, the Center has put emphasis on prevention of hemophilic arthropathy and guidance for delaying its progress. For this purpose, X-ray examinations as well as measurement of the range of motion and muscle strength are performed at every comprehensive outpatient clinic service, and any changes are carefully observed $[6,7]$. If the progress of hemophilic arthropathy is recognized, it is then confirmed whether infusion of blood coagulation products should be performed according to the fundamental rule as soon as possible after bleeding, and if arthropathy becomes worse in spite of infusion according to the fundamental rule, then prophylactic infusion should be recommended. If the disease progresses in spite of aggressive prophylactic infusion, a regular infusion two or three times per week should be considered. Since home infusion therapy is a useful measure for any of the early, prophylactic or regular treatments, we have actively introduced home infusion therapy under the direction of a nurse coordinator or outpatient clinic nurses [8].

Another approach to hemophilic arthropathy is orthopedic therapy. Guidance for rehabilitation training at home for muscle strengthening or restoring the range of motion is given based on findings from the comprehensive outpatient clinic service. Preparation of supporters or prosthetic appliances, and adjustment of shoes such as sole inserts or extensions for leg length discrepancy are provided as necessary. We have also studied the material of the supporter or sole inserts. For severe arthropathy that cannot be treated with physical therapy, invasive treatment including intraarticular irrigation, synovectomy, or preparation of an artificial joint have been provided. Irrigation of articular cavity with 2,000 $-5,000 \mathrm{ml}$ of physiological saline has been effective for reducing chronic pain or enlargement and for preventing the progress of arthropathy in relatively early cases of hemophilic arthropathy accompanied by synovitis.

\section{Dental/Oral Surgical Approach}

Because many hemophiliacs cannot effectively brush their teeth due to a bleeding tendency during brushing, many suffer from dental caries and paradentitis. Therefore, prevention and treatment of dental caries and paradentitis are important subjects in comprehensive medical care for hemophiliacs. The Center provides regular oral examination by dentists, as well as guidance for brushing, scaling, and early treatment of dental caries. As a result, the number of hemophiliacs with moderate or severe dental caries has dramatically decreased. 


\section{Support for School Attendance, Employment and Marriage}

Fewer cases have been observed recently in which hemophilic children are forced to enter a school for physically and mentally handicapped children. On the contrary, hemophilic children require more support for adapting to general schooling. Especially at the time of entering kindergarten or primary school, nursery teachers or school teachers are likely to be anxious in accepting such children. Therefore, if requested by the parents of the patient, the Center prepares and gives them a booklet describing characteristics of the patient's clinical symptoms and how to deal with bleeding. On the other hand, recently we have been faced with an increasing number of consultations regarding the refusal to attend school by hemophilic children. In many of these cases, bleeding or pain is more likely to be an excuse, but the real reason is usually friction of human relationships in family or school. Therefore, we try to counsel not only the patient and his/her family, but also to discuss the problems with the school members to create a better environment.

There have been various consultations about employment and maladjustment to the workplace. In addition to concerns of HIV infection, prolonged economic depression has made it difficult for patients to find a desirable job. At the Center, a member who was once Director of a Public Employment Security Office gives advice on employment and jobs based on his rich experience and human relations cultivated during his working days [9].

There are many difficult problems in counseling for marriage between HIV infected patients. It is the policy of the Center to actively assist in the marriage if the bride-to-be recognizes the fact of the patient's HIV infection and nevertheless wants to marry him. More than five HIV infected patients have already gotten married under these conditions.

\section{Aid for Hemophiliac Association}

Although hemophiliacs and their family have organized patient associations in each prefecture or hospital where they receive treatment, the concerns regarding HIV infection has discouraged the activities of patient associations. However, the exchange of information and friendship among patients/families has a great significance. Furthermore, the patient association is a good channel to pass on information from the Center to patients who have not visited the Center. Thus, the Center has actively backed the activities of patient associations in the Kyushu district. We have placed special emphasis on support for summer camp: 20 to 25 members including physicians and nurses of the Center and volunteer students of 
our University have participated in an annual summer camp. Participation of students in the summer camp is effective as an early exposure to patients: for example, their experiences in the summer camp may encourage a smoother acceptance of HIV infected persons in their future practice.

\section{Care of HIV Infected Persons [10-12]}

Each relevant department is responsible for preventing the development of disease and the treatment of patients with disease based on clinical symptoms, while the Center is responsible for counseling and consultation about problems in the patient's daily life. Since our hospital is designated as a regional core hospital for AIDS, there are many visitors or consultations on line by HIV infected persons or those with HIV anxiety other than hemophiliacs. The Center serves as the first contact for these cases.

\section{Problems in Management of the Center}

One of the managemental problems of the Center is its fragile financial base. Although the Center is officially recognized as one of the organizations of the University Hospital of Occupational and Environmental Health, we mainly depend for our financial base on donation from the Rotary Club, and a grant from the Foundation for Prevention of AIDS and the Ministry of Health and Welfare's Research Group.

Another problem is the care of patients who live in distant areas from the Center. Our Genter was designated as the North Kyushu Hemophilia Center for the purpose of aiding hemophiliacs in the northern part of Kyushu. However, the Center is forced to cover a wide area, including Chugoku District (Western Honshu) and the whole of Kyushu, because this is the only hemophilia center on the island of Kyushu. For remote patients, the Center gives support by contacting the physician in charge or the home doctor, but only a few patients receive careful and sufficient care in each medical institution. HIV infected hemophiliacs especially have a lot of problems. Therefore, as one measure to solve this problem, the Hemophilia Nurse Coordinator Study Meeting in Kyushu District was started from 1989, aiming at the creation of a network among nurses. This Study Meeting, which has now changed its name to Kyushu District HIV Nursing Study Meeting, organizes staying study meeting once a year, and member nurses in each region are engaged in consultation with patients in cooperation with the Center. One great source of concern is that due to the frequent reshuffle of personnel among nurses, members of the Study Meeting often leave the clinical practice of hemophilic or HIV care. 


\section{Evaluation of Activities of the Center}

The Genter has been in operation for 10 years, supported by volunteer work by many members. As a result, it is difficult to make an objective evaluation of the improvement in the QOL of patients. We have experienced many cases where individual patients who had just been able to move in a wheel chair, obtained autonomic movement. However, since they can not be compared with patients who have not received total care, we cannot conclude that these experiences, or the improvement in the range of motion, muscle strength and oral hygiene are attributable to comprehensive care. A survey on the satisfaction level for daily life was conducted [13], but it was not a precise evaluation because of the possible presence of bias. The establishment of an evaluation method is one of our future projects.

\section{Summary and Conclusion}

One of our objectives in establishing the Hemophilia Center was to create a model of a total care system for chronic diseases which develop in the childhood and continue through adulthood. We also believe that the comprehensive medical care system should be introduced not only for the care of hemophiliacs but also for those with every chronic refractory disease.

It may be a surprise that in a university hospital, which is likely to lack cooperation between departments, this kind of cross sectional support system, even extending to activities outside the hospital, has been continued. This success owes much to the understanding and consideration by successive Directors of the Hospital and the Professors (Directors) of every department, the enthusiastic efforts by members of the Center who have continued their volunteer work for the purpose of improving the QOL of patients, and the cooperation by students of the Volunteer Study Club. We also have to mention the advice and guidance by Dr. Minoru Inagaki (now at the National Children's Hospital) who established the first substantial hemophilia center in Ogikubo Hospital, and Dr. Kaneo Yamada, present Visiting Professor in the Faculty of Medicine, St. Marianna University. We would like to thank every one who has supported the activities of the Center. Finally, we strongly hope that this total care system will become popular among those responsible for caring of patients with other chronic refractory diseases. 


\section{References}

1. Nakamura Y, Ariyoshi N, Asakura A, Nakamura T, Kim H \& Shirahata A (1986) : The status of seroconversion of anti-HTLV-III (human T-lymphotropic virus type III) antibody in 45 hemophiliac patients. The Journal of Kyushu Hematological Society 34: 92-98

2. Shirahata A (1994): Present state in Japanese hemophiliacs with human immunodeficiency virus infection. Pediatrics of Japan 35: 985-993

3. Shirahata A, Yamada K, Inagaki M, Nishioka H \& Watanabe J (1990) : Hepatitis in Japanese hemophiliacs. In : Proceedings of the Sixth International Symposium on Hemophilia Treatment. National Foundation of Japan for Promotion of Comprehensive Care of Hemophiliacs. Kyoritsu Printing, Tokyo pp 161-174

4. Naka Y (1991) : Support of activities of daily life in hemophilic patients. Jpn J Nursing Arts 37: $87-92$

5. Naka Y (1991): Assessment of problems of hemophilic patients and the method of planning of nursing for them. Jpn J Child Nursing 14:1600-1605

6. Saeki C, Omine S \& Ogata H (1987): Muscle strength of knee joint in hemophiliacs. Orthopaedic Surgery and Traumatology 36:645-647

7. Kohshi K, Ogata H \& Hachisuka K (1989): Muscle weakness in adult hemophiliacs. Jpn J Rehabil Med 26: 153--157

8. Shirahata A, Shiiki M, Naka Y \& Ono O (1992): Benefits and problems of home infusion therapy. Jpn J Clin Hematol 33: 1802-1808

9. Hachisuka K \& Yamaguchi M (1994) : Vocational counseling for the hemophiliacs. Sogo Rihabiriteshon 22: 983-987

10. Naka Y, Hagiwara Y, Matsuo K, Nakano N, Nagatome T, Yoshimura Y, Ishihara M, Shirahata A, Ono O \& Yamaguchi M (1993) : The groping for nursing in people with HIV/AIDS. Jpn J Nursing 13(10): 78-81

11. Ono O. \& Shirahata A (1994) : Adjustment to disability of hemophiliacs and hemophiliacs with HIV infection. Sogo Rihabiriteshon $22: 843-848$

12. Yanaga Y, Ono O \& Shirahata A (1996) : Counselling for HIV-positive hemophiliacs in Japan. Haemophilia 2: 109-113

13. Tanaka S, Hachisuka K, Ogata H \& Shirahata A (1994): Employment and satisfaction with daily life in adult hemophiliacs. Jpn J Rehabil Med 31: 113-118 
血友病の包括医療

一産業医科大学病院北部九州血友病センターの活動—

白幡 聡，小野 織江，矢永由利子，山口 政夫，大里 敬一 産業医科大学病院 北部九州血友病センター

要旨：代表的な先天性出血性素因である血友病患者は，“些細な外傷でも大きな出血になる ことがある”という体質ゆえに, 就学, 就労, 結婚など社会的な面で様々なハンディ キャップを背負っている．また，繰り返す関節内出血の結果生じる関節の可動域制 限や筋力の著しい低下が日常生活を困難にしている。ささらに血液凝固因子製刜を介 したヒト免疫不全ウイルスやC 型肝炎ウイルスの感染が, 身体的のみならず心理的 にも血友病患者に大きな負担をもたらしている。このように血友病患者が抱える多 様な問題に対处するために，われわれは 1984 年に産業医科大学病院の中に北部九 州血友病七ンターを開設した，以来，10 年以上にわたり血友病患者の QOL の改善 をめざして活動してきたので，これまでの北部九州血友病センターの歩みを紹介す ると共に, センター運営上の問題点について言及した。

J UOEH (産業医大誌)，18 ( 2): 141-150 (1996) 